ENTERTAINMENTS IN SAMUEL PEPYS'S DIARY:

\title{
VERSES FROM JOHN EVELYN AND A SONG TO MOCK SIR WILLIAM PENN
}

The enduring friendship of the diarists Samuel Pepys and John Evelyn began during Second Dutch War (1665-67) when Pepys was Clerk of the Acts to the Navy Board and Evelyn was a Commissioner for the Sick and Wounded. ${ }^{1}$ The plague helped bring them together. During the epidemic, the officials of the Navy Board evacuated from the City of London to Greenwich, a short walk from Evelyn's home at Deptford. Pepys relished the social life among the evacuees at Greenwich: 'I have never lived so merrily ... as I have done this plague-time' was how he summed up his experiences in $1665 .^{2}$ One evening in particular was among the best that Pepys had ever had. He went for supper at the home of the merchant Captain George Cocke where he found, among others, Sir John Mennes (a fellow Navy Board member) and Evelyn. Reports had just arrived that Pepys's patron, Lord Sandwich, had captured some much-needed Dutch prizes to fund the war effort:

the receipt of this news did put us all into such an extasy of joy, that it inspired into Sir J. Mennes and Mr. Eveling such a spirit of mirth, that in all my life I never met with so merry a two hours as our company this night was.

Mennes's fame as a wit and a poet dated from before the civil wars, yet he had met his match in Evelyn:

\footnotetext{
${ }^{1}$ On their early contact, see Particular Friends: The Correspondence of Samuel Pepys and John Evelyn, ed. Guy de la Bédoyère (Woodbridge: The Boydell Press, 1997 repr. 2005), 29-30.

${ }^{2}$ The Diary of Samuel Pepys, ed. Robert Latham and William Matthews, 11 vols (1970-83; repr. London: HarperCollins, 2000), VI, 342. Future references are to this edition.
} 
Among other humours, Mr. Eveling's repeating of some verses made up of nothing but the various acceptations of May and Can, and doing it so aptly, upon occasion of something of that nature, and so fast, did make us all die almost with laughing, and did so stop the mouth of Sir J. Mennes in the middle of all his mirth (and in a thing agreeing with his own manner of Genius) that I never saw any man so out-done in all my life; and Sir J. Mennes's mirth too, to see himself out-done, was the crown of all our mirth.

Pepys's cryptic reference to verses on 'the various acceptations of May and Can' requires explanation. 'Acceptations' here means 'accepted meanings'. With Mennes leading the amusing conversation, it seems a question had had been raised about the correct usage of 'may' (indicating permission) and 'can' (indicating ability). This led to Evelyn reeling off some verses he had memorized that aptly fitted the occasion. The poem has not been previously identified. However, a Restoration manuscript miscellany in the British Library indicates what these lines were and why Evelyn's rapid recital of them so impressed Pepys:

I think indeed $\mathrm{y}^{\mathrm{t}}$ whoso May \& Can

Can never May, for May must Can obay

Yet in $\mathrm{y}^{\mathrm{t}}$ May \& Can, May will as man

For May ${ }^{3}$ may Will, tho his Will can not May

or thus.

I grant indeed $\mathrm{y}^{\mathrm{t}}$ whoso May \& Can

May Can \& Will, for May dos Can obey

But whoso Can \& Will may Will as man

For man may Will, tho his Will never May. ${ }^{4}$

\footnotetext{
${ }^{3}$ Probably an error for 'Man'.

${ }^{4}$ British Library, MS Add. 18220, fol. $123^{\mathrm{v}}$.
} 
It was, in effect, a tongue-twister. In 1654 the first four lines had appeared in print, as part of a much longer nonsense poem published by John Taylor the water poet. They were bracketed together with the comment 'Deep Ppilosophy' [sic] - a satirical encouragement to extract and memorize them:

I grant indeed, that whoso may and can

Can never may, sith may doth can abey:

But he that can and will, may will as man,

But man can will, yet his will cannot may. ${ }^{5}$

The eight-line manuscript version of the 'May and Can' poem, which better matches Pepys's description of Evelyn's 'repeating' verses, is found a collection begun in 1667 by John Watson, the vicar of Mildenhall in Suffolk. Watson kept up the collection until his death in 1673, at which point another hand took over. ${ }^{6}$ The positioning of the 'May \& Can' verse shows it was entered after Watson's death, in late 1678 or 1679 . It follows a version of Latin poem by James Carkesse concerning his experiences in lunatic asylums in 1678, a poem which first appeared in print in 1679. In his print collection Carkesse - who had been a clerk in the Navy Ticket office - wrote of his rivalry with Pepys, which he dated to the mid 1660 s. $^{7}$ This naval link may be sheer coincidence, as other surrounding poems in the manuscript do not share such associations.

\footnotetext{
5 John Taylor, The Essence, Quintessence, Insence ... of Nonsence upon Sence [London, 1654], 21.

6 'John Watson (CCEd Person ID 128611)', The Clergy of the Church of England Database 1540-1835, <http://www.theclergydatabase.org.uk/> [accessed 18 June 2018].

${ }^{7}$ MS Add. 18220, 'Carkase in Bedlam', fol. 123v'; [James Carkesse], Lucida Intervalla (London, 1679), 5, 42. Nicholas Jagger, 'Carkesse, James (b. c. 1636), poet', Oxford Dictionary of National Biography <http://www.oxforddnb.com.ezproxy4.lib.le.ac.uk/view/10.1093/ref:odnb/9780198614128.001.0001/o dnb-9780198614128-e-4666> [18 June 2018]. The next datable item after the poem has the year '1679', fol. $125^{\mathrm{v}}$.
} 
Harold Love speculates that the individual who continued the collection after John Watson's death may have been Watson's brother Thomas. Thomas Watson was the usher (or deputy master) at Charterhouse school and had supplied John with many poems. ${ }^{8}$ Support for (if not absolute confirmation of) Love's theory comes from the fact that the last item in the new hand is dated 1679 which, it transpires, was the year of Thomas Watson's death. ${ }^{9}$ The signature on Thomas Watson's will of September 1679 also shares multiple characteristics with the second hand in the miscellany. ${ }^{10}$ I have not been able to establish a direct connection between the Watsons and Evelyn, though their social circles overlapped in several respects. Evelyn had at least one link to Thomas Watson in the late 1670 s via Thomas's superior, William Erskine, the master of Charterhouse from 1677. Evelyn and Erskine had known each other since at least early 1660s when both were active in the Royal Society. In 1681, Evelyn recorded dining at Charterhouse with Erskine, 'my worthy friend'. ${ }^{11}$ It's possible an earlier such dinner conversation led to the verses finding their way to the Watson miscellany.

Witty verses were prized currency in table talk although, as another cryptic reference from Pepys's diary demonstrates, this could be as much about expressing antagonism as earning admiration. On 4 January 1667, Pepys held a Christmastide dinner for his colleagues on the Navy Board and their

\footnotetext{
${ }^{8}$ Harold Love, English Clandestine Satire 1660-1702 (Oxford, 2004), 271, 272.

${ }^{9}$ MS Add. 18220 , fol. $125^{v}$ 'The Commons Petition to y ${ }^{e}$ K. 1679 '.

${ }^{10}$ Will of Thomas Watson, 20 Sept 1679, proved 12 Nov. 1679, London Metropolitan Archives, DL/C/B/005/MS09172, will 74, via Ancestry.com, Wills and Probates 1507-1858 database <ancestry.co.uk> [accessed 23.6.18].

${ }^{11}$ Alsager Vian, 'Erskine, William (d. 1685), headmaster', in Oxford Dictionary of National Biography <http://www.oxforddnb.com.ezproxy4.lib.le.ac.uk/view/10.1093/ref:odnb/9780198614128.001.0001/o dnb-9780198614128-e-8877> [accessed 18 June 2018]. Michael Hunter, The Royal Society and its Fellows 1660-1700, 2nd edn (Oxford, 1994) 130, 142, 150. The Diary of John Evelyn, ed. E.S. de Beer (Oxford, 1955), IV, 262. An earlier link was via John Watson's association with the North family, who supplied a number of the verses. His patron Sir Henry North of Mildenhall (c.1609-1671) was the uncle of Evelyn's close friend Margaret Blagge (1652-78).
} 
families. Part of the amusement (at least for Pepys) came in poking fun at Navy Commissioner Sir William Penn. Penn 'was much troubled to hear the song I sung - The new Droll - it touching him home'. ${ }^{12}$ The editors of the complete edition of Pepys were not able to locate the piece from this brief allusion. It is the song 'The old Rownhead. And the new torncoate', which is found in a manuscript miscellany now in the Bodleian Library. The first two lines announce 'A new droll made by a new quiblinge pate / of an old Rowndhead $\mathrm{y}^{\mathrm{t}}$ is worne out of date'. ${ }^{13}$ The song comes from in a section of the miscellany that can be dated to between $1666-68$. Two poems before 'The Old Rownhead' is a version of 'The Session of the Poets' (here called 'Apollo's second Sessions') which, in another miscellany carries the date 1666, though the editor of Poems on Affairs of State suspected an allusion in the poem to Thomas Shawell indicated a later date of $1668 .{ }^{14}$ Several pages after 'The Old Rownhead' comes 'An Answer to $y^{e}$ French declaration' (a declaration of war made in January 1666), along with a poem on Earl of Clarendon's fall in the latter half of $1667 .{ }^{15}$ Pepys was regaling his guests with a droll that was indeed 'new' even if the satire was on a familiar theme.

The first part of the song ridiculed the Roundhead's nefarious practices under the Commonwealth. This was a man 'Who in the name of god began all his afaires / Who Converted $\mathrm{y}^{\mathrm{e}}$ people $w^{\text {th }}$ pistols \& Prayers' (fol. $47^{v}$ rev). He went onto destroy the Church and the people's liberties, seizing royal and church lands for his own family. The second half ('The New Turncoate') described his rapid transformation after the Restoration: he adopted court fashions in clothing and wit and switched from godly speech to modish blasphemy. Now he 'Tryhumphes as if hee had twice over came yee / And hath turned his yea, \& nay, Into sinkmee and Dammee' (fol. $46^{\mathrm{v}} \mathrm{rev}$ ). The courtly Roundhead relished his

${ }^{12}$ Pepys, Diary, VIII, 5.

${ }^{13}$ Oxford, Bodleian Library, MS Rawl. Poet 84 , fol. $47^{\vee}$ rev. The miscellany has the ownership mark of Giles Frampton 1659 (a student at Balliol, Oxford, 1662 and the Middle Temple, London, in 1664) and the mark 'R.N. 1663'.

${ }^{14}$ MS Rawl. Poet 84, fol. 52av rev. George deF. Lord, ed., Poems on Affairs of State: Augustan Satirical Verse, 1660-1714 (New Haven and London, 1963), I, 327-37.

${ }^{15}$ MS Rawl. Poet 84 , fols. $39^{v}$ rev, $34^{v}$ rev. 
power to dole out patronage in return for bribes, while secretly promoting sedition and scheming against the King.

This was not, on the face of it, a close fit for Sir William Penn. Penn had served as a Vice Admiral and as an Admiralty Commissioner for Parliament during the Interregnum. Under Charles II he continued as a naval commander and also acted as a Navy Commissioner. Although he had served against the King and personally benefitted from the seizure of royalist lands, he had not turned courtier. However, the lyrics chimed pleasingly with Pepys's view of Penn and his vices. Since 1662, Pepys had come to see Penn as bent on undermining him at the Navy Board while hypocritically professing friendship. Penn, Pepys judged, was 'a counterfeit rogue', 'a false knave', and a 'perfidious rogue'; he acted towards Pepys and his wife 'as he doth always, mighty civil to us, though I know he hates and envies us'. Pepys also regarded him as a taker of exorbitant bribes. By early 1667 Penn was in favour at court as a result of his conduct during the Second Dutch War. Pepys did not want to alienate him, yet remained highly suspicious. At his party he observed that Penn 'seems mightily to be kind to me ... but I believe not a little troubled to see my plenty'. ${ }^{16}$ The 'new turncoat' was just such a false man as Penn appeared, someone who 'although in his hearte he doth highly obhor yee / He'el tell you sweete sir I have kindnis for yee' (fol. $46^{r}$ rev).

One particular source on Penn's past must have made the song seem especially apt. In 1663 Pepys had recorded in detail his lengthy gossip session with Robert Blackborne, a former navy official who had information about Penn's career in the 1640 s and 1650s. Penn, Blackborne said, 'was alway a conceited man and one that would put the best side outward, but that it was his pretence of sanctity that brought him into play'. He had been 'a great brother' of the millenarian 'Fifth-monarchy men', before allegedly turning Quaker just before the Restoration, and then re-joining the established Church. Pepys was amused at how Blackborne imitated the way Admiralty Commissioners and admirals such as Penn used to talk in determining promotions: 'how they would, with a sithe [sigh] and casting up the eye, say, "Such a man fears the Lord" - or, "I hope such a man hath the Spirit of God," and such things as

16 Pepys, Diary, IV, 68, 401; V, 144, 231; VIII, 4-5. 
that'. Penn and others like him fitted the idea of a roundhead 'Who in the name of god began all his afaires'. Indeed, Penn with his changes of religious allegiance now appeared to Blackborne 'the greatest hypocrite in the world'. ${ }^{17}$ Pepys's gave his own opinion of Penn's religion later in 1667. Penn's son William (future Quaker leader and founder of Pennsylvania) had, Pepys noted, become 'a Quaker again, or some very melancholy thing'. This was 'pleasant' (amusing) because his father was 'such a hypocritical rogue, and at this time an atheist'. ${ }^{18}$

Pepys thought that his singing touched Penn home. That may not, however, have been how others in the group perceived it. Certainly, the first few lines of 'The New Turncoate' fitted the host better than his guest:
Hee hath left Dod \& Cleaver for Fletchers play Bookes
Ye shall finde him at Courte in all Corners \& Nookes
And though his false head hath false hayre, yett still he lookes
Like a new turncoate of $y^{e}$ times (fol. $47^{v}$ rev)

'Dod \& Cleaver' was John Dod and Robert Cleaver's puritan advice manual A Godlie Forme of Householde Governement, first published under their names in 1610 . Pepys was not an admirer of this well-known work, yet since the early 1660s he had become less conscientious about his religious reading habits and had taken to spending lavishly on plays and playbooks, John Fletcher's among them. ${ }^{19}$ He had also put in time walking the Whitehall galleries 'among the Courtiers', noting with pleasure that he was becoming 'pretty well-known among them'.$^{20}$ In 1663 , in a daring move, he had

\footnotetext{
${ }^{17}$ Pepys, Diary, IV, 375-6.

${ }^{18}$ Pepys, Diary, VIII, 595.

19 Pepys, Diary, V, 280. Loveman, Samuel Pepys and his Books: Reading, Newsgathering and Sociability, 1660-1703 (Oxford, 2015), 37-9, 142.

${ }^{20}$ Pepys, Diary, IV, 1 cf. III, 239.
} 
sought to place himself at the cutting edge of court fashion by adopting a periwig. ${ }^{21}$ When he sung his song in 1667 he was wearing 'false hayre' while Penn, judging by a near contemporary portrait, had not adopted a wig. Pepys certainly did not see himself as a roundhead turncoat, but his enemies had not forgotten that he had once worked as a clerk in Oliver and Richard Cromwell's governments: in 1664 one slighted merchant (a colleague's relative) spread gossip that Pepys favoured his 'Fellow-Traytours' when awarding navy contracts. ${ }^{22}$ In performing the song, Pepys was not just needling Penn and undermining Penn's status; he was also implicitly signalling to his colleagues his confidence that he was not implicated in the satire. Pepys had no fear that the song's charges might be turned back upon the singer.

\section{KATE LOVEMAN}

University of Leicester

\footnotetext{
${ }^{21}$ Pepys, Diary, IV, 362.

${ }^{22}$ Pepys, Diary, V, 131.
} 